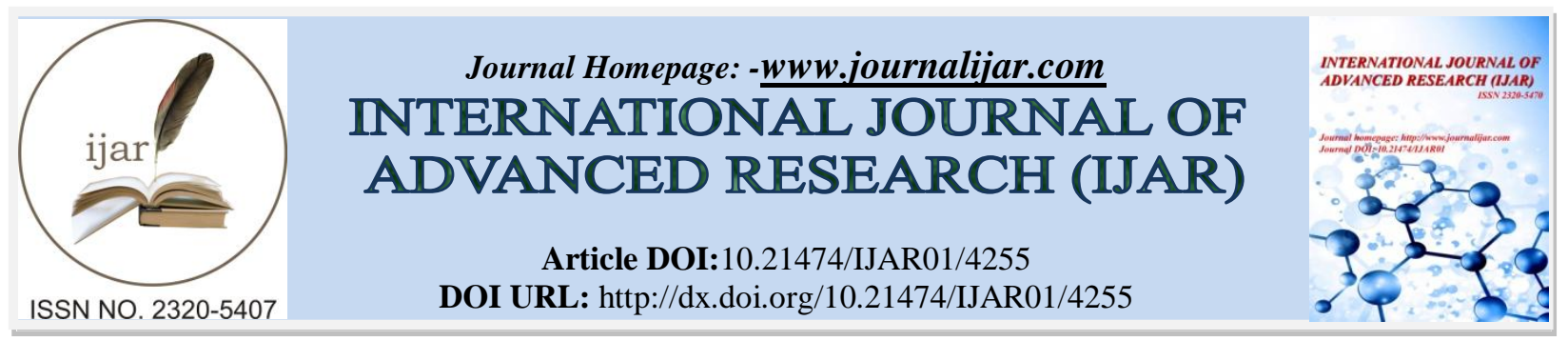

RESEARCH ARTICLE

\title{
QUALITY CONTROL OF WATER OF THE SENEGAL RIVER FOR THE AGRICULTURAL USE (ROSSO, MAURITANIA).
}

\section{Fatimetou Salma M.M.O.S ${ }^{1,2}$, B. BABA ${ }^{1,2}$, M. NAJY ${ }^{1}$, M. Lachhab ${ }^{1}$, B. A Dick ${ }^{2}$, Kankou M.O.S.A ${ }^{2}$, K. Elkharrim ${ }^{1}$ and "D. Belghyti"}

1. Laboratory of Agro-physiology, Biotechnology, Environment and Quality, Faculty of Science, University Ibn Tofail133.14000, Kenitra-Morocco.

2. Unit of research water-pollution and Environment, University of Nouakchott ELAssriya, Mauritania.

\section{Manuscript Info}

[..........................

Manuscript History

Received: 26 March 2017

Final Accepted: 29 April 2017

Published: May 2017

Key words:-

Hydrochimy, Standards, Irrigation,

Senegal River, Mauritania.

\section{Abstract}

The Senegal River's water has important repercussions on hydraulic, hydro-chemical balances and the mobilizable hydrological resources which condition in the national socio-economic future of Mauritania. This river's water is used as drinking water and water of irrigation without any preliminary control of healthiness.

For these reasons we tried to carry out a physicochemical evaluation, to know whether this river's water is suitable for irrigation. A hydrochimic analysis was carried out in five stations at the zone of the high delta of the Senegal River (city of Rosso, Mauritania) during every season (dry clod season, hot dry season and rainy season) of the years 2015-2016.These anal yes related to elements $\mathrm{pH}$, electric Conductivity, $\mathrm{Ca}^{2+}, \mathrm{Mg}^{2+}, \mathrm{Na}^{+}, \mathrm{K}^{+}, \mathrm{HCO}_{3}{ }^{-}, \mathrm{CL}^{-}, \mathrm{NO}_{3}^{-}$, RAS, $\mathrm{Na} \%$ ) in the water of the river. The analysis comprises volumetric analysis, spectroscopic, $\mathrm{pH}$ measures and Conductimeter.

The interpretation of theresults, using Richards and Wilcox diagrams in comparison with the directives of FAO, shows that the river's water is slightly salty, where its conductivity varies between $(54-405 \mu \mathrm{s} / \mathrm{cm})$, and it undergoes a sodic chimsm with predominance of carbonate ions at the average (1,6méq/l) and, thus, it belongs to the class $\mathrm{C} 1 \mathrm{~S} 1, \mathrm{C} 2$ S1.

This water is in general suitable for agricultural use, but it requires an updated quality control in particular the reduction of the domestic effluents located on the shore of this river.

Copy Right, IJAR, 2017,. All rights reserved.

\section{Introduction:-}

Water is an essential factor for agriculture.Constitutive of the plants, it also transports all the substances necessary to the plant.The irrigation is the activity which consumes the most water; it absorbs more than $85 \%$ of the water controlled by humans (Horning, 1973). Since the sixties the practice of the irrigation is at the origin of an increase in the total food production in all third world countries (De Regt, 1990).

The quality of the water used for irrigation is an essential parameter for the output of agriculture, the maintenance of the productivity of the ground and environmental protection. Thus, the physical properties and chemical of the 
ground, such as its structure (stability of the aggregates) and its permeability, are very sensitive to the type of ions, potentially exchangeable, present in irrigation water.The effect of irrigation water quality on agriculture is a concern for the agronomists and economists in charge of the development of the territories of the arid and semi-arid regions (Monition, 1969).

Agriculture itself only contributes with $22.82 \%$ of the national GDP of Mauritania with a useful agricultural surface (UAS) representing less than $0.5 \%$ of the national territory estimated at 502,000 ha (BanqueMondial, 2014).Irrigated agriculture represents 88,000 ha of UAS, and it is located mainly in the zone of high delta of the Senegal River, according to the regional management of agriculture of Trarza (Kankou, 2004).

Agricultural installations of the Senegal River introduced new agriculture beside the old ones. Indeed the meadows of rice along the river banks, the market gardening and fruit farming take an important place in the irrigated perimeters (Diallo, 2012). The main aim of our present research is to study the water quality of the high delta of the Senegal River used in irrigation in the city of Rosso, in order to evaluate the advantages and the disadvantages of its agricultural use.

\section{Presentation Of The Zone Of Study:-}

The Senegal River spreads over four countries: Guinea, Mali, Mauritania and Senegal and covers an area of $340,000 \mathrm{~km}^{2}$. It is fed by three principal affluents: Bafing, Bakoye and Falamé, and all the three take their sources in the solid mass of Fouta Djalon in Guinea. The basin is divided into three great areas: the high basin which is mountainous, the valley which is known for a long time as a pastoral agricultural border area and the delta which is an area of great biological diversity and which shelters several wetlands (Duvail, 2002). The zone of study relates to the high delta of the Senegal River particularly the city of Rosso. The importance of this region depends on its geographical location as the Senegal River's mouth, the central border, where it does not constitute a passage between West Africa and East Africa or between urban waste areas. It also represents an important aspect of rural development. The city of Rosso is characterized by stable which are separated by argillaceous, flat-bottomed valleys, within the area of Trarza in the south of Mauritania, between the latitudes $16^{\circ} 30$ and longitudes $14^{\circ}$ and 16 ${ }^{\circ}$ (Official website of AMI, 2011). The climate of the zone of study is of the Sahelian type. It is characterized by an important variation of temperature between depending on day and night time as well as weak annual precipitations. One distinguishes three seasons: the dry cold season of the November to March, the dry, hot season of April and mid-July and rainy season of the mid-July to October. The Senegal river plays an important role in the life of the town inhabitants; the main economic activities of the city are carried on the bank of this river like the breeding and agriculture. The town of Rosso is drinking water by a station of water treatment of the river. In addition the city does not have a network of safe cleansing of the channels specified for the discharge of the rainwater towards the river. These channels are misused by the residents who use them for the discharge of waste waters and oils of Motors. To evaluate the Senegal river irrigation water quality, we chose five stations laid out in the city of Rosso. These stations were selected according to their accessibility, and their proximity to the sources of pollution. 


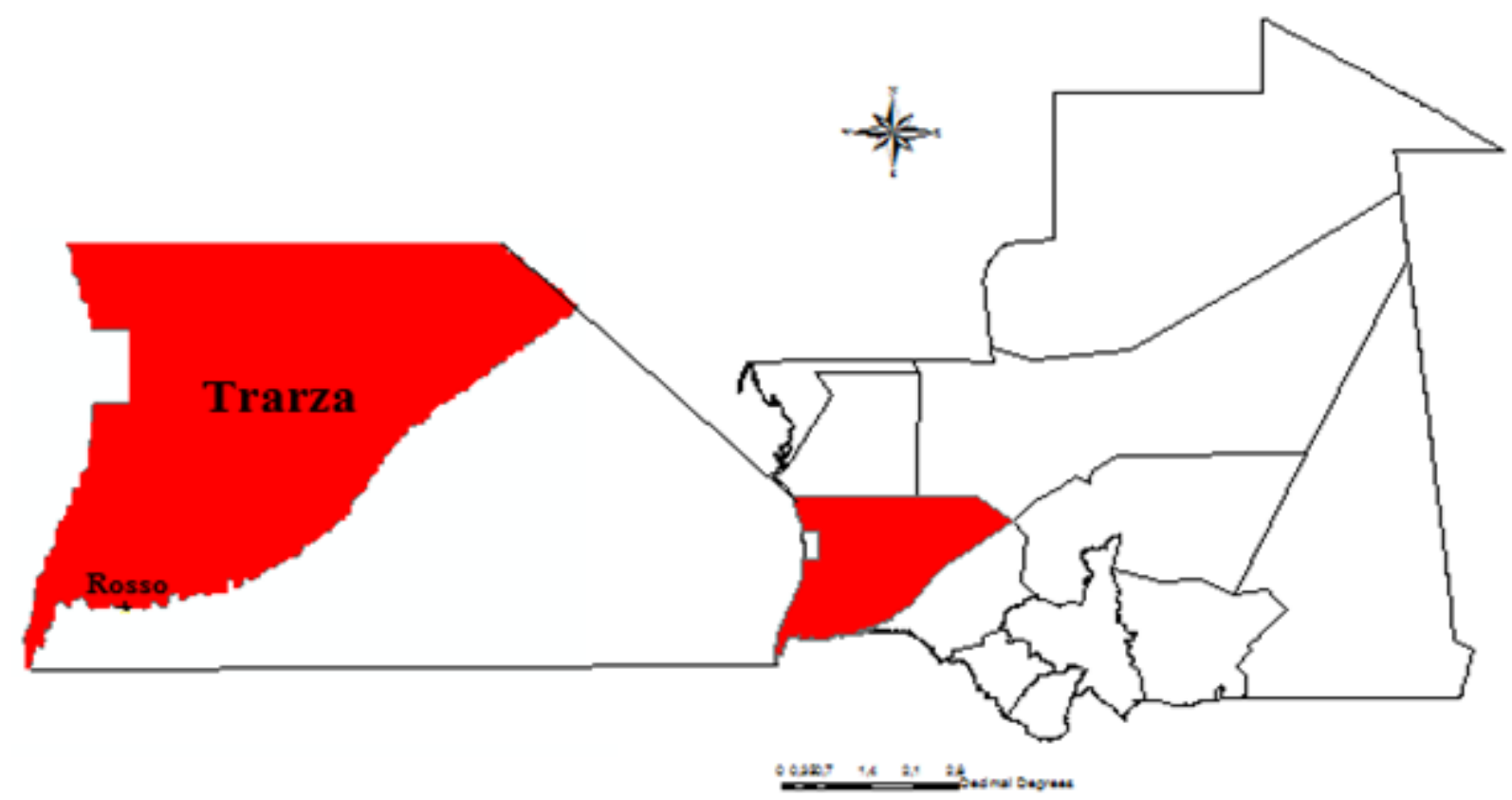

Figure 1:- Localization of the study area in Mauritania.

\section{Equipment and Methods:-}

\section{Sampling:-}

The taking of water samples from the Senegal river was carried: The dry clod season (January), the hot dry season (May) and the rainy season (September) of the years2015-2016 in the zones where this water is not stagnant but current. These samples were carried out in plastic bottles of 4 Liter, clean, by means of water from the sample and they were subject total immersion in water hermetically filled in order to avoid any contamination.

\section{Methods of Analysis:-}

The analyses were carried out within the research unit Water-pollution and Environment at the University of Nouakchott ELAssriya.

The $\mathrm{pH}$ is measured using a $\mathrm{pH}$ measures portable of brand HANNA series 9,024. Electric conductivity (CE) was measured, using a conductimeter of the type HANNA instrument $\mathrm{HI}$ 8,733. Nitrates $\left(\mathrm{NO}_{3}{ }^{-}\right)$are proportioned using a new portable photometer Wagtech 7100 "WTD (Wag-WE10441)". Alkaline metal sodium $\left(\mathrm{Na}^{+}\right)$and potassium $\left(\mathrm{K}^{+}\right)$are proportioned by photometer with flames. Calcium $\left(\mathrm{Ca}^{2+}\right)$, magnesium $\left(\mathrm{Mg}^{2+}\right)$, Chloride $\left(\mathrm{Cl}^{-}\right)$, and bicarbonate $\left(\mathrm{HCO}_{3}{ }^{-}\right)$are proportioned by volumetric method of Mohr in the presence of the selective mediums (Rodier, 1996).

The Sodium Absorption Ratio (RAS) and the percentage of the sodium in water (\% $\mathrm{Na}$ ) which are used in combination with eclectic conductivity in the method of Richards and Wilcox (Derradji, 2004), are expressed by the relations following:

$$
\mathrm{RAS}=\frac{\mathrm{Na}}{\sqrt{\frac{\mathrm{Ca}+\mathrm{Mg}}{2}}} \% \mathrm{Na}=\frac{\mathrm{Na}+\mathrm{K}}{\mathrm{Ca}+\mathrm{Mg}+\mathrm{Na}+\mathrm{Ka}} \times 100
$$

\section{Results and Discussion:-}

The physicochemical results of the 30 samples taken in two years 2015-2016 are illustrated by Table1. The evaluation of the irrigation water quality requires the use of a grid of quality to which one must refer to judge if the water is appropriate or not for the irrigation. We chose the directives "guides" of the interpretation of the irrigation water quality recommended by FAO (Bulletin FAO ${ }^{\circ}$ 29.1976). These directives are adopted by many countries and used within the framework of Californian agriculture by the service of the popularization, the experimental farm and the teaching staff of the University of California (Ayers et Westcot 1976). 
Table 1:- Physicochemical results of the water of the high delta of the Senegal River.

\begin{tabular}{|c|c|c|c|c|c|c|}
\hline \multirow{2}{*}{ Variables } & Min & Ave & Max & \multicolumn{3}{|c|}{ FAO 1979 } \\
\cline { 5 - 7 } & & & & $\begin{array}{c}\text { Not of } \\
\text { problems }\end{array}$ & $\begin{array}{c}\text { Increasing } \\
\text { problems }\end{array}$ & $\begin{array}{c}\text { serious } \\
\text { problems }\end{array}$ \\
\hline $\mathrm{pH}$ & 6.06 & 7.01 & 8 & $6.5-8.4$ & & \\
\hline $\mathrm{CE}(\mu \mathrm{s} / \mathrm{cm})$ & 54 & 146,3 & 405 & $<750$ & $750-2000$ & $>3000$ \\
\hline $\mathrm{Ca}^{2+}(\mathrm{mg} / \mathrm{l})$ & 3.12 & 6.7 & 14.4 & - & - & - \\
\hline $\mathrm{Mg}^{2+}(\mathrm{mg} / \mathrm{l})$ & 0.45 & 3.44 & 9.6 & - & - & - \\
\hline $\mathrm{Na}^{+}(\mathrm{mg} / \mathrm{l})$ & 4 & 8.66 & 38 & - & - & - \\
\hline $\mathrm{K}^{+}(\mathrm{mg} / \mathrm{l})$ & 1 & 4.26 & 28 & - & - & - \\
\hline $\mathrm{HCO}_{3}{ }^{-}(\mathrm{méq} / \mathrm{l})$ & 0,29 & 0,6 & 2,4 & $<1.5$ & $1.5-8.5$ & $>8.5$ \\
\hline $\mathrm{CL}^{-}(\mathrm{méq} / \mathrm{l})$ & 0.14 & 0.35 & 2.53 & $<4$ & $4.0-10$ & $>10$ \\
\hline $\mathrm{NO}_{3}{ }^{-}(\mathrm{mg} / \mathrm{l})$ & 0 & 1.48 & 4.4 & $<5$ & $5.0-30$ & $>30$ \\
\hline $\mathrm{RAS}$ & 1.9 & 4.31 & 13.5 & $<6$ & $6-9$ & $>9$ \\
\hline $\begin{array}{l}\text { Montmorillonite - Smectite } \\
\text { Illite - Vermiculite } \\
\text { Kaolinite - Sesquioxides }\end{array}$ & & & & $<8$ & $8-16$ & $>16$ \\
\hline $\mathrm{Na} \%$ & 45 & 57 & 72 & - & - & -24 \\
\hline
\end{tabular}

The $\mathrm{pH}$ of its water east varies between $6.06-7.58$ and located in the normal range (6.5 to 8.4) according to the directives of FAO. Electric conductivity (CE) translated the degree of total mineralization; it informs us about the rate of salinity and the effect of water on the permeability of the grounds. Conductivity varies $54-405 \mu \mathrm{s} / \mathrm{cm}$ is lower of the grid $(750 \mu \mathrm{S} / \mathrm{cm})$, water is classified in the category " "Not of Problems "": Thus, no problem of permeability related to total salinity is to be considered. According to the directives, there is a problem with bicarbonate when their content exceeds 1, 5 meq/l. For the Senegal River, the bicarbonate rates $\left(\mathrm{HCO}_{3}{ }^{-}\right)$lay between 0, 29-2.4 méq/1 and classify water in the category "' Increasing problems "': Who appears by a white deposit on the fruits or the sheets, and who decreases the fair, average quality and with the taste of the fruits. Chlorine $\left(\mathrm{Cl}^{-}\right)$varies between 0 $0.81 \mathrm{meq} / \mathrm{l}$, nitrate $\left(\mathrm{NO}_{3}{ }^{-}\right)$varies graft $1.08-4.4 \mathrm{méq} / \mathrm{lis}$ lower grid of $\mathrm{FAO}(4 \mathrm{meq} / \mathrm{l}, 5 \mathrm{mg} / \mathrm{l})$. The river's water is classified in the category of " Not of Problems "": there is no risk of chlorine on the agriculture sensitive and there is no risk of nitrogen on the production and the maturation of the agriculture. Sodium Absorption Ratio (RAS) vary between 1, 9-13, 5. Then the Senegal River's water constitutes a serious risk for the permeability of the soil types: montmorillonite-Smectite and illite-Vermiculite. However, it represents no risk for the permeability of the soil type: Kaolinite - Sesquioxides.

Salinity can involve consequent adverse effects because of the fixing of sodium and chlorides by colloids of the ground. Sodium then exerts a harmful action on the vegetation in an indirect way, by degrading the soil property physics. Under this action, the grounds become compact and asphyxiating for the plants (Todd, 1980). The choice of these two methods is closely related to the parameters that the two methods call for (Sodium, calcium, magnesium, potassium, electric conductivity). (Richards, 1954), by taking into account the two parameters: Electric conductivity (E.C $25^{\circ} \mathrm{C}$ ) and Sodium Absorption Ratio (SAR) proposed a diagram of classification comprising 16 classes corresponding to the couple risks alkaline saline. This classification is very useful and reliable to characterize irrigation water. From this classification and after having deferred all the water supply points on the diagram of Richards (figure 2), one could release the presence of the two following classes:

C1 S1: Water of good quality: to be used with precautions with the sensitive plants.

C2 S1: Water of average quality: to be used with a precaution in the heavy, drained soils and for the sensitive plants (fruit trees). 


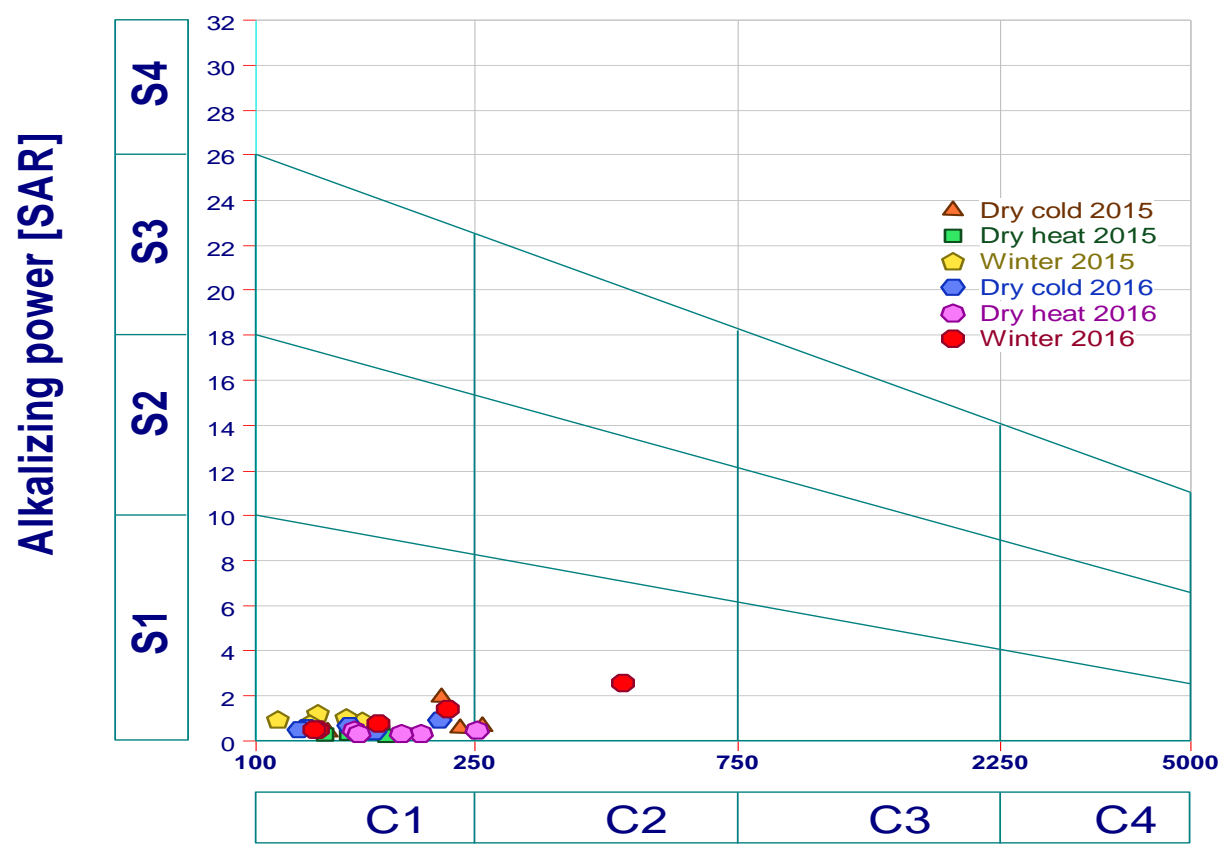

Conductvity in $\boldsymbol{\mu S} / \mathbf{c m}$

Figure 2:- Projection of water of the Senegal River in the diagram of Richards.

Generally, the plants badly support the water saturated with sodium. The classification of Wilcox based on electric conductivity and the sodium content in the water which is expressed as a percentage $(\% \mathrm{Na})$. This classification defines five water classes: excellent, good, acceptable, poor and bad.

According to the presentation of figure : All the water supply points of the Senegal River are in the category: "excellent."

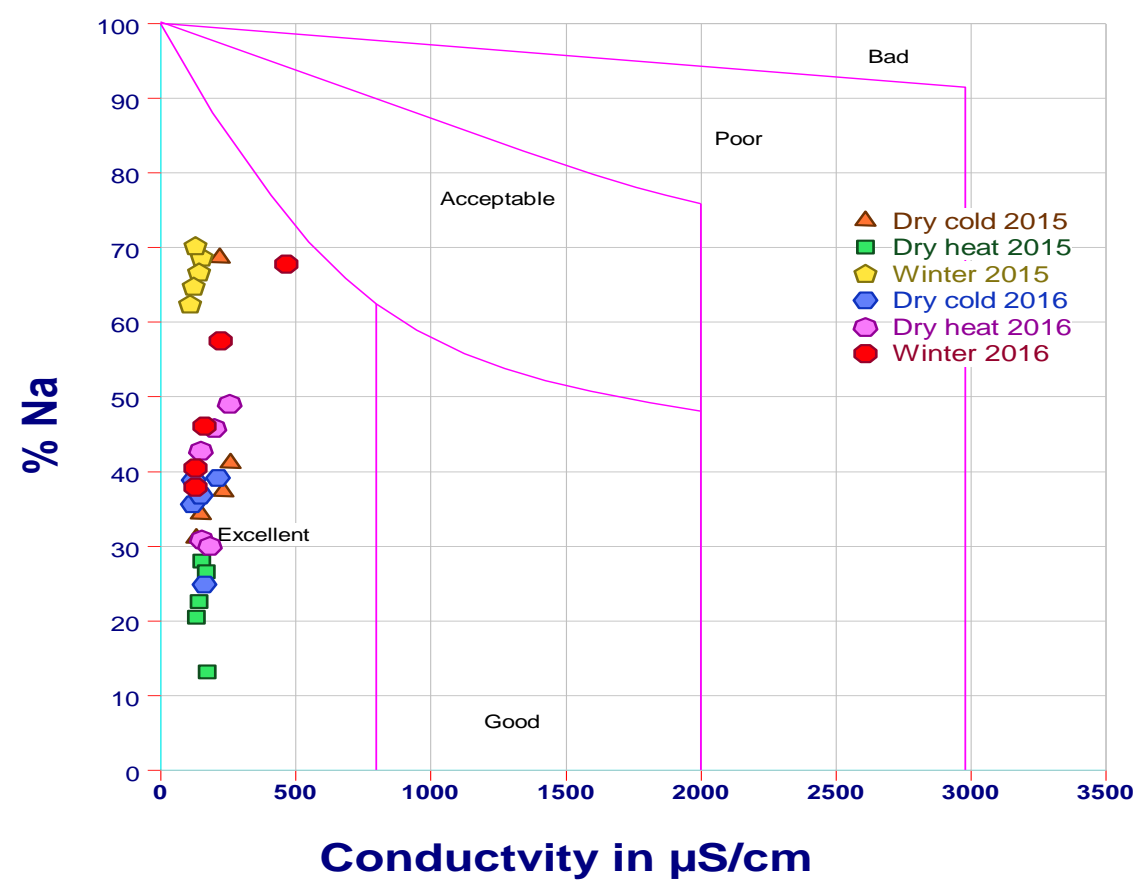

Figure 3:- Projection of water of the Senegal River in the digraph of Wilcox. 


\section{Conclusion:-}

The results of the physicochemical analyses of the Senegal river's water used for ends of irrigation in farms, compared with the values guides (FAO) andanalyzed by means of Richard and Wilcox methods lead us to conclude that the Senegal river's water is classified in the category of " No problem "" particularly with regard to salinity, the effect on the permeability, risks of nitrogen and chlorine. But itundergoes a sodic chimsm with predominance of carbonate ions. In other words, the Senegal river is classified by Wilcox in the category 'excellent' and belongs to classes C1S1, C2S1according to Richards, it bewitches telling water to low salinity, average quality with good and using with precautions in the heavy ground's evil drained and for the sensitive plants (fruit trees).

Water of the Senegal River is generally suitable for the irrigation, but requires a quality control required and brought up to date by the authorities concerned.

\section{Bibliographical References:-}

1. Ayers RS et Westcot DW, (1976); La qualité de l'eau en agriculture. Bull. FAO N ${ }^{\circ} 29$ Rome 81p.

2. Banque Mondial. (2014); Rapport Final sur l'Appui à l'élaboration de la Stratégie de Développement du Secteur Rural de la Mauritanie.

3. DeRegt B. (1990) ; L'irrigation et la culture du riz au Suriname. Revue le Courrier n²4 Nov. décembre pp 9495.

4. Derradji F. (2004); Aptitude des eaux de la vallée de la Seybouse à l'irrigation (Nord-Est algérien). Revue Sécheresse $\mathrm{N}^{\circ}$ 4, Vol 15, pp: 353-60.

5. DIALLO A.D. (2012); Etude de la qualité de l'eau de la vallée du fleuve Sénégal utilisée en irrigation dans la plaine de M’Pourié à Rosso (Mauritanie). ScienceLib Editions Mersenne : Volume 4, $\mathrm{N}^{\circ} 120608$ ISSN 21114706.

6. DUVAIL S. (2002), Modifications récentes de l'hydrosystème deltaïque Mauritanien et Politiques de gestion de l'eau dans le contexte de l'après-barrage Mémoire de DEA, Université Louis Pasteur, UFR de Géographie, Dakar; 141p.

7. FAO. (1976); La qualité de l'eau en agriculture.Bulletin d'irrigation et drainage $n^{\circ} 29$. Rome.

8. Horning H M. (1973) ; Rôle de l'aménagement rationnel de l'eau d'irrigation au niveau des exploitations. Séminairerégional FAO/PNUD Damas. 7-13 décembre 1971.pp 10-21.

9. http://fr.ami.mr/Depeche-14056.html

10. Kankou M.O.S.O. (2004), Vulnérabilité des eaux et des sols de la rive droite du Fleuve senegal en mauritanie - etude en laboratoire du comportement de deux pesticides. Thèse de Doctorat, Université de Limoges, Option Chimie et Microbiologie de l'Eau, France

11. MONOTION L. (1969); Données sur l'utilisation des eaux selon leur qualité chimique. Rapport BRGM inédit 69 SGL 122 HYD.

12. Rodier J, (1996) ; Analyse de l'Eau, 8éme édition. Denod, Paris, 1383.

13. Todd K, (1980); Groundwater hydrology. Second edition. New York : John Wiley \& Sons, 510 p. 